\title{
Article \\ Entomopathogenic Nematodes for the Management of Plum Curculio in Highbush Blueberry
}

\author{
Ana Luiza Sousa ${ }^{1}$, Cesar Rodriguez-Saona ${ }^{2}{ }^{\mathbb{D}}$, Robert Holdcraft ${ }^{2}$, Vera Kyryczenko-Roth ${ }^{2}$ \\ and Albrecht M. Koppenhöfer ${ }^{1, *}$
}

1 Department of Entomology, Rutgers University, New Brunswick, NJ 08901, USA; avs102@sebs.rutgers.edu 2 P.E. Marucci Blueberry and Cranberry Center, Department of Entomology, Rutgers University, Chatsworth, NJ 08019, USA; crodriguez@njaes.rutgers.edu (C.R.-S.); rob.holdcraft@rutgers.edu (R.H.); vera.kyryczenko@rutgers.edu (V.K.-R.)

* Correspondence: a.koppenhofer@rutgers.edu

check for updates

Citation: Sousa, A.L.;

Rodriguez-Saona, C.; Holdcraft, R. Kyryczenko-Roth, V.;

Koppenhöfer, A.M.

Entomopathogenic Nematodes for the Management of Plum Curculio in Highbush Blueberry. Biology 2022, 11, 45. https://doi.org/10.3390/ biology11010045

Academic Editor: Cheng-Gui Han

Received: 29 November 2021

Accepted: 26 December 2021

Published: 29 December 2021

Publisher's Note: MDPI stays neutral with regard to jurisdictional claims in published maps and institutional affiliations.

Copyright: (C) 2021 by the authors. Licensee MDPI, Basel, Switzerland. This article is an open access article distributed under the terms and conditions of the Creative Commons Attribution (CC BY) license (https:// creativecommons.org/licenses/by/ $4.0 /)$.
Simple Summary: The plum curculio, a snout beetle native to North America, is one of the most important fruit-feeding pests of cultivated blueberry in New Jersey. Application of certain entomopathogenic nematode (EPN) species has shown efficacy in plum, peach, and apple orchards when targeting the larval stage of plum curculio in soil. Prior to our research, however, EPNs have never been tested for control of this pest in highbush blueberries. In 2020, laboratory and field studies were conducted to: (1) determine the persistence of different EPN species in acidic blueberry soil; (2) compare the virulence of these EPNs to plum curculio larvae and pupae; and (3) compare the efficacy of these EPNs to control this pest in blueberry fields. In 2021, field studies were conducted to confirm the efficacy of one of the EPN species. Steinernema riobrave persisted better in blueberry sand, was the most virulent EPN against plum curculio larvae and pupae and was highly efficacious for suppression of larvae and pupae of this pest in blueberry fields. Steinernema riobrave has the potential to become an important component in the management of plum curculio in highbush blueberry.

\begin{abstract}
Conotrachelus nenuphar Herbst (Coleoptera: Curculionidae) is a key pest of stone and pome fruits in the United States. Application of certain entomopathogenic nematode (EPN) species has shown efficacy in some crops when targeting the larval stage of $C$. nenuphar in soil. To date, however, no EPNs have been tested for the control of this pest in highbush blueberries. In 2020, laboratory and field studies were conducted to: (1) determine the persistence of Steinernema riobrave, S. carpocapsae, $S$. feltiae, and Heterorhabditis bacteriophora in acidic blueberry soil; (2) compare the virulence of these EPNs to C. nenuphar larvae and pupae; and (3) compare the efficacy of these EPN species to control this pest in blueberry fields. The greatest persistence in blueberry soil was exhibited by $S$. riobrave followed by $S$. carpocapsae. Superior virulence was observed in S. riobrave against $C$. nenuphar larvae and pupae. Promising levels of virulence were also observed in S. carpocapsae and S. feltiae against the larvae, but $S$. scarabaei had low virulence. In the field, S. riobrave provided significantly higher levels of $C$. nenuphar suppression $(90 \%)$ than the other EPNs. The field efficacy of $S$. riobrave against C. nenuphar at low and high rates was confirmed in 2021. Steinernema riobrave has the potential to become an important component in the management of $C$. nenuphar in highbush blueberry.
\end{abstract}

Keywords: Conotrachelus nenuphar; biological control; blueberry; Vaccinium corymbosum; Steinernema riobrave

\section{Introduction}

The plum curculio, Conotrachelus nenuphar Herbst (Coleoptera: Curculionidae), is a major pest of several fruit crops (peach, apple, plum, cherry, and blueberry) in North America [1-3]. In early spring, overwintered adult weevils emerge and usually begin moving from wooded areas into cultivated crops to feed, mate, and oviposit in fruits. 
Damage to fruit results from feeding and oviposition scars produced by C. nenuphar adult females and from larval burrowing. Internal larval feeding can cause early fruit drop, which typically occurs at or near the molt to the fourth-instar larvae. Infested blueberries often turn prematurely blue before experiencing early drop [4]. Fruit drop increases survivorship of the larvae that exit the fallen fruit when fully mature (fourth instar) and burrow into the soil $(2.5-5 \mathrm{~cm})$ to pupate $[1,5]$. Complete time in the soil can be as long as 30 days, with approximately eight of those days spent as a teneral adult [6,7]. After emergence, adults feed on fruits and migrate to overwintering sites in forested areas and unmanaged orchards or surrounding areas $[1,7,8]$.

Above-ground applications of insecticides continues to be the main management tactic used to suppress C. nenuphar adults [9]. Due to environmental and regulatory concerns, approaches need to be developed to control $C$. nenuphar that reduce the overall amount of synthetic insecticide used such as the application of entomopathogenic nematodes (EPNs), targeting C. nenuphar stages in the soil [10-14].

Entomopathogenic nematodes, Steinernema spp. and Heterorhabditis spp., are obligate parasites of insects. The free-living EPN stage, the infective juvenile (IJ), enters hosts through natural openings (mouth, anus, spiracles, and cuticle), and after entering the host's hemocoel, releases symbiotic bacteria, which are primarily responsible for killing the host within 24-48 h. The nematodes complete 1 to 3 generations within the host, whereafter IJs exit the cadaver to search out new hosts [15].

EPNs are effective at controlling a variety of economically important pests, including the larvae of several weevil species (Coleoptera: Curculionidae) that spend a large portion of their life cycle in the soil [16]. Previous studies have already indicated the potential of several EPN species in the genus Steinernema to suppress soil-dwelling stages of C. nenuphar in apple, plum and peach orchards, with Steinernema riobrave Cabanillas, Poinar, and Raulston being the most virulent species, demonstrating a significant reduction in C. nenuphar emergence in all field trials [11-14,17-19]. EPN applications tend to be most efficacious to soil or cryptic habitats due to the nematode's sensitivity to desiccation and ultraviolet (UV) radiation [15]. Therefore, fourth-instar larva, pupa, and adult of C. nenuphar are potential targets for EPNs, since these stages occur in or on the soil [1].

To date, no EPNs have been tested for the control of $C$. nenuphar in highbush blueberries (Vaccinium corymbosum L.). In this study, we conducted laboratory and blueberry field experiments to: (1) determine the persistence of the EPNs S. riobrave, Steinernema carpocapsae (Weiser), Steinernema feltiae (Filipjev), and Heterorhabditis bacteriophora Poinar in acidic blueberry soil; (2) compare the virulence of these EPNs to $C$. nenuphar larvae and pupae; and (3) determine the efficacy of S. riobrave, S. carpocapsae, S. feltiae, and Steinernema scarabaei Stock \& Koppenhöfer -to control this pest in highbush blueberry fields.

\section{Materials and Methods}

\subsection{Laboratory Experiments}

2.1.1. Soils, Insects, Nematodes

Substrates collected for studying the effect of soil type on EPN persistence were a sandy loam (61\% sand, $27 \%$ silt, $12 \%$ clay; $2.3 \%$ organic matter (OM); $\mathrm{pH} 5.9$ ) and an acidic blueberry sand (93\% sand, 7\% silt, 0\% clay; 5.1\% OM; pH 3.9). The substrates were air-dried, sieved through no. 5 (4 mm openings) and no. 10 (2 mm openings) sieves, pasteurized ( $3 \mathrm{~h}$ at $72{ }^{\circ} \mathrm{C}$ ), and aerated for at least 1 week before use [20]. Soil moisture release curves were established using the filter paper method for determination of soil matric potential [21].

Commercial strains of $S$. carpocapsae (commercial product Millenium ${ }^{\circledR}, \mathrm{BASF}$, Research Traingle Park, NC, USA) and S. feltiae (Nemasys ${ }^{\circledR}$ ) were obtained from BASF (Research Triangle Park, NC, USA) and of H. bacteriophora (Nema-green ${ }^{\circledR}$ ) from e $\sim$ nema (Schwentinental, Germany); S. riobrave (strain 355) was obtained from Dr. David Shapiro-Ilan (USDA-ARS, Byron, GA, USA). Steinernema scarabaei AMK001 originated from our EPN collection (Turfgrass Entomology Lab, New Brunswick, NJ, USA). 
To standardize IJ quality for experiments, the EPNs were cultured in last instar larvae of the greater wax moth, Galleria mellonella (L.) that were obtained from Rainbow Mealworms (Compton, CA, USA). The emerging IJs were harvested over a period of 7-14 days from emergence traps and stored in filtered tap water in tissue culture flasks at $8{ }^{\circ} \mathrm{C}$ for 7-21 days before use. Fresh starter cultures were obtained every year for the experiments and EPNs were only reared once through wax moth larvae to avoid potential modification of the commercial strains during laboratory culture. Conotrachelus nenuphar adults were collected in early spring using beating sheets from unsprayed blueberry fields and peach orchards located at a commercial organic blueberry farm (Hammonton, NJ, USA) and at the Rutgers Agricultural Research and Extension Center (Bridgeton, NJ, USA), and taken to the Blueberry/Cranberry Entomology laboratory at the Philip E. Marucci Center for Blueberry and Cranberry Research and Extension of Rutgers University, Chatsworth, NJ, USA. Green thinning apples were placed in sweater boxes with $C$. nenuphar adults for oviposition and starting the $C$. nenuphar larvae rearing at room temperature $\left(22-25^{\circ} \mathrm{C}\right)$ and a photoperiod of 14:10 (L:D) h following methods in Amis and Snow [22].

\subsubsection{Nematode Persistence in Different Soil Types}

Blueberry sand was prepared at $-10 \mathrm{kPa}$ soil water potential $(10 \%$ soil moisture $w / w)$ and sandy loam at $-14 \mathrm{kPa}(14 \%$ soil moisture $w / w)$ and the substrates were filled into 200-mL plastic cups ( $55 \mathrm{~mm}$ height $\times 75 \mathrm{~mm}$ diam). Each cup received $100 \mathrm{~g}$ moist substrate. The substrate was uniformly compacted to a depth of approximately $25 \mathrm{~mm}$ by tapping the cups and lightly pressing on the substrate surface. Two hundred IJs of S. carpocapsae, S. feltiae, S. riobrave, and H. bacteriophora were added in $250 \mu \mathrm{L}$ tap water to the substrate surface. Then the cups were placed into plastic boxes with wet paper towel to reduce moisture loss and stored at room temperature. Every 7 days, the cups were opened for air exchange, weighed, and water was added if the weight of the cup had decreased. EPN persistence in the soil was assessed by saturation baiting with last instar wax moth larvae [23]. At 0, 7, 14, 28, and 56 days after treatment (DAT), five cups from each substrate type were opened, the soil loosened with a scupula, 10 wax moth larvae added, and the cups sealed again. Every 3 days, dead wax moth larvae were replaced with live ones and the baiting concluded after 12 days ( 4 baiting rounds) after the first larvae were added. Dead larvae were incubated for an additional 6 days and then dissected to confirm EPN infection. For each cup, the total number of infected larvae was recorded [20]. The experiment was conducted twice at room temperature $\left(22-25^{\circ} \mathrm{C}\right)$.

\subsubsection{Nematodes Virulence of against C. nenuphar Larvae and Pupae}

The experiments were conducted at room temperature $\left(22-25^{\circ} \mathrm{C}\right)$ and the blueberry soil was prepared at $-10 \mathrm{kPa}$ soil water potential. For the $C$. nenuphar larvae experiment, each 200-mL plastic cup ( $55 \mathrm{~mm}$ height $\times 75 \mathrm{~mm}$ diam) received $100 \mathrm{~g}$ moist blueberry soil. Five $C$. nenuphar fourth-instar larvae were added per cup and the cups sealed with translucid plastic lids. Larvae that did not enter the soil within $1 \mathrm{~h}$ were replaced. Steinernema carpocapsae, S. feltiae, S. riobrave, and S. scarabaei were applied in $250 \mu \mathrm{L}$ tap water to the substrate surface at the rates of 100, 200, and $400 \mathrm{IJs} /$ larva. Untreated control cups received water only. At 7 and 14 DAT, the cups were checked, and infected larvae were recovered, rinsed in water, and dissected immediately to confirm EPN infection. Each EPN species and rate had 7 replicates and the experiment was conducted twice.

For C. nenuphar pupae, two different experiments were conducted using $30 \mathrm{~mL}$ plastic cups ( $3.3 \mathrm{~cm}$ height $\times 4 \mathrm{~cm}$ diam) filled with $20 \mathrm{~g}$ of moist blueberry soil. One pupa was released onto the soil surface and the vials were sealed with a translucid plastic lid. Pupae that did not enter the soil within $1 \mathrm{~h}$ were replaced. In the first experiment, S. carpocapsae, S. feltiae, S. scarabaei, and H. bacteriophora were applied in $250 \mu \mathrm{L}$ tap water to the substrate surface at $400 \mathrm{IJs} /$ pupa. Untreated control cups received water only. Each treatment had 36 vials as replicates and the experiment was conducted twice. In the second experiment, $S$. riobrave was applied in $250 \mu \mathrm{L}$ tap water to the substrate surface at 100,200 , and 
$400 \mathrm{IJs}$ / pupa. Untreated control cups received water only. Each treatment had 40 vials and the experiment was conducted twice. For both experiments, the cups were checked at 7 and 14 DAT, and infected pupae were recovered, rinsed in water, and dissected immediately to confirm EPN infection.

\subsection{Field Experiment: 2020}

The field experiment was conducted in an organically maintained blueberry field at the Philip E. Marucci Center, Chatsworth, NJ, USA. Highbush blueberries (25-year-old variety 'Bluecrop') were spaced $0.61 \mathrm{~m}$ between bush crowns and $5.49 \mathrm{~m}$ between rows center-to-center.

Four EPN species were tested. Steinernema riobrave, S. carpocapsae, and S. feltiae were selected based on results from the persistence and virulence laboratory experiments. Steinernema scarabaei AMK001 was included because it can provide excellent control, potentially even long-term suppression of another important pest of highbush blueberries: larvae of the oriental beetle, Anomala orientalis (Waterhouse) [24]. Due to its potential for long persistence, $S$. scarabaei could control A. orientalis larvae even though they would not be present yet at the appropriate timing for C. nenuphar EPN applications [20,25].

Experimental arenas to determine the efficacy of the EPNs consisted of 45-cm diam circular plots $\left(1590 \mathrm{~cm}^{2}\right)$ placed between two adjacent blueberry bushes within a row in the blueberry field. On 23 June 2020 (10:00-12:00 EST, sunny, 25-30 $\left.{ }^{\circ} \mathrm{C}\right)$, the plots were treated with approximately 79,500 IJs of a given EPN species (50 IJs/ $\left.\mathrm{cm}^{2}\right)$ applied by hand sprayer in a volume of $36 \mathrm{~mL}$ per plot. The EPNs were then watered in with $1000 \mathrm{~mL}$ of water (6.3 mm water) using a watering can. Then 100 blueberries infested with C. nenuphar larvae in the laboratory were evenly distributed on the soil surface of each plot before the plots were covered with pyramidal emergence cages (Figure 1), as described by Piñero et al. [18]. The pyramidal emergence cages $(43.7 \mathrm{~cm}$ diameter base; $64 \mathrm{~cm}$ tall) were made of aluminum window screen and the top (white) portion of a boll weevil trap (ISCA technologies, Riverside, CA, USA) was fitted with a stainless-steel hose clamp at the top of each cage. This permitted the capture of adult $C$. nenuphar that, upon emergence, walked upward onto the interior of the capturing boll weevil trap. The edges of the cages were buried about $5 \mathrm{~cm}$ deep in the soil to prevent $C$. nenuphar adults from escaping.

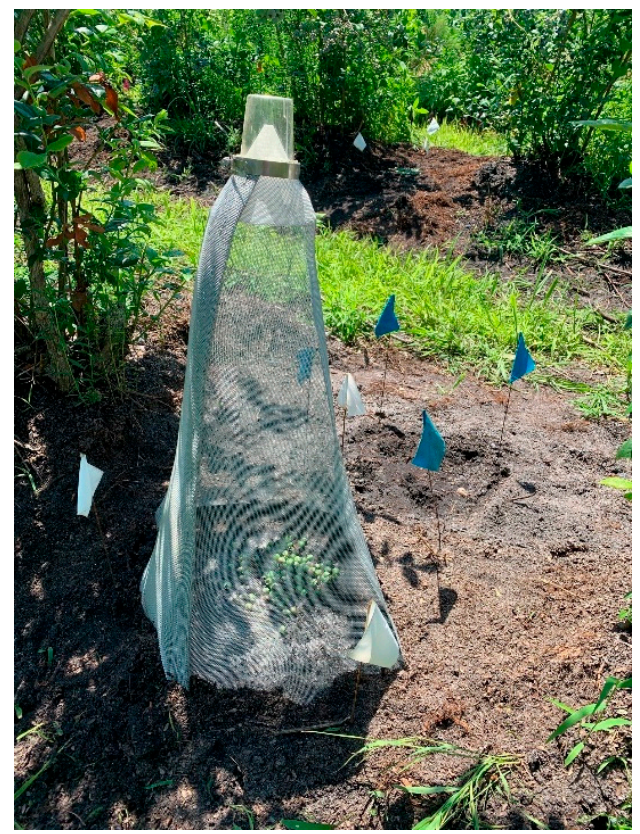

Figure 1. Pyramidal emergence cage ( $43.7 \mathrm{~cm}$ diameter base; $64 \mathrm{~cm}$ tall) made of aluminum window screen and a boll weevil trap fitted with a stainless-steel hose clamp at the top (lower left) and arenas $(30 \times 30 \mathrm{~cm})$ for the determination of entomopathogenic nematode persistence (upper right). 
Treatments were a water-only control, S. scarabaei, S. riobrave, S. feltiae, and S. carpocapsae and there were six cages per treatment. To determine EPN efficacy, cages were inspected twice weekly for 6 weeks (10 August 2020), and any adults emerged collected. The total number of $C$. nenuphar adults emerged per cage was compared among treatments. Weather data were obtained from the weather station at Chatsworth, NJ, USA $\left(39^{\circ} 42^{\prime} 55.97^{\prime \prime} \mathrm{N}\right.$, $74^{\circ} 30^{\prime} 39.24^{\prime \prime}$ W) (Office of the New Jersey State Climatologist; Rutgers University, New Brunswick, NJ, USA), and downloaded from the New Jersey Weather and Climate Network website (www.njweather.org/ accessed on 10 September 2021).

Arenas for the determination of EPN persistence consisted of $30 \times 30 \mathrm{~cm}$ area directly adjacent to the emergence cages between the blueberry bushes (Figure 1). EPNs were applied at the same time as for the efficacy experiment at the same rate $\left(50 \mathrm{IJs} / \mathrm{cm}^{2}\right)$ and the EPNs watered in with $560 \mathrm{~mL}$ (6.3 mm water) using a watering can. Untreated control plots received water only. These plots did not receive infested blueberries. EPN persistence was measured by baiting soil samples from each plot with wax moth larvae. Soil samples were taken just after EPN application, and at 7 and 21 days after application. On each sampling day, four soil cores $(2.5 \mathrm{~cm}$ diameter $\times 5 \mathrm{~cm}$ depth) were taken with an Oakfield sampler per arena, combined and sealed in a plastic bag and brought to the laboratory. The soil cores were broken up and thoroughly mixed and a 25-g subsample combined with $75 \mathrm{~g}$ of pasteurized blueberry soil and placed in a 200-mL cup. Due to the at least initially high numbers of IJs expected per sample we only used $25 \mathrm{~g}$ per cup. As baiting of such a small soil amount with 10 wax moth larvae seemed difficult, we combined the sample soil with the additional pasteurized blueberry soil. After adding 10 wax moth larvae per cup, the samples were baited for four consecutive 3-day baiting rounds as described in the laboratory persistence experiment. After each 3-day period, any dead wax moth larvae were collected and replaced with fresh living ones. The dead larvae were rinsed in tap water and placed on moist filter paper for another 3 days before being dissected under a dissecting microscope to determine presence of EPNs. The cadavers were assigned to EPN species based on the cadaver color and morphology of any adult males within them [26,27]. Data were the total number of EPN-infected cadavers of the treatment EPN species recovered over the 12-day baiting period.

\subsection{Field Experiment: 2021}

Based on our findings in the 2020 field and laboratory experiments, we selected S. riobrave as the only EPN species for the 2021 field experiment. The experiment was conducted in two organically maintained blueberry fields at the Philip E. Marucci Center, Chatsworth, NJ, USA. In both fields, highbush blueberries were spaced $0.61 \mathrm{~m}$ between bush crowns and $5.49 \mathrm{~m}$ between treated rows center-to-center. Field 1 contained 7-year-old bushes of mix varieties, whereas field 2 contained 25-year-old bushes of the variety 'Duke'. The methodology used for both efficacy and persistence determination was the same as used in the 2020 experiment unless otherwise mentioned. In 2021, C. nenuphar larvae rather than infested berries as in 2020 were used to infest the plots in hopes of increasing the number of adults emerging and reducing variability in adult emergence. One day prior to treatment applications, 50 C. nenuphar larvae (fourth instar) were added to the soil surface of each efficacy plot and allowed to dig into the soil. Treatments consisted of 0,25 , and 50 S. riobrave IJs $/ \mathrm{cm}^{2}$ with seven replicates per treatment in each field for both efficacy and persistence determination. Treatments were applied on 8 June 2021 (10:00-12:00 EST, sunny, $25-30{ }^{\circ} \mathrm{C}$ ) in field 1 and on 16 June 2021 (10:00-12:00 EST, sunny, 25-30 ${ }^{\circ} \mathrm{C}$ ) in field 2 . Field 2 was treated later because the fruit in this field ripened later than those in field 1 . Weather data were obtained as described for the 2020 field experiment.

\subsection{Statistical Analysis}

Laboratory EPN persistence data were subjected to analysis of variance (ANOVA) and Tukey test for means separation. Data were analyzed by soil type with experiment repetition, EPN species, and baiting date as factors. For the laboratory virulence experiments, a 
generalized linear model (glm) with a binomial distribution corrected by Bonferroni-Holm test was used to analyze the effects of rates, EPN species (EPNs), and EPN species $\times$ rates on the C. nenuphar mortality for both larva and pupa at 7 and 14 DAT.

For the 2020 field experiment, data were normalized by $\log (x+1)$ transformation and subjected to ANOVA and LSD for means separation. For the 2021 field experiment, data were not normally distributed and could not be normalized through transformations. They were therefore first analyzed by field using Kruskal-Wallis non-parametric test followed by Dunn's test for means separation. Since data in both fields followed the same pattern, we then analyzed the data combined for both fields. Field persistence data were normalized by square root transformations and subjected to repeated measures ANOVA and means separated with Tukey test. Differences among means in all experiments were considered significant at $p<0.05$ (Supplementary Materials).

\section{Results}

\subsection{Nematode Persistence in Different Soil Types}

Significant interactions between EPN species and days after treatment were detected in sandy loam soil $(d f=12,180 ; \mathrm{F}=2.54 ; p<0.001)$ and acidic blueberry soil $(d f=12,180$; $\mathrm{F}=2.82 ; p<0.001$ ). In both soils, the number of infected waxworms (=infection) was always the highest in S. riobrave and the lowest in H. bacteriophora. However, S. riobrave infection was significantly higher than S. carpocapsae infection only on day 14 in sandy loam and day 28 in blueberry soil. Steinernema carpocapsae infection was always higher than $H$. bacteriophora infection in both soils and also higher than S. feltiae infection on days $0-28$ in sandy loam and days 0,7 , and 28 in blueberry soil. Steinernema feltiae infection was significantly higher than $H$. bacteriophora infection on days 14-56 in sandy loam and days 7-56 in blueberry soil.

In the sandy loam (Figure 2), all EPN species declined significantly over time. However, the decline occurred the quickest in H. bacteriophora with a significant decrease compared to 0 DAT already at 7 DAT and the lowest infection already reached at 28 DAT. The three Steinernema spp. followed the same pattern with the first significant decrease observed at 28 DAT and the lowest infection at 56 DAT.

In the blueberry soil (Figure 2), infection declined the quickest in H. bacteriophora, following the same pattern as in sandy loam, with the first significant decrease at 7 DAT and the lowest infection already at 28 DAT. In the Steinernema spp., decline tended to be slower than in sandy loam, but a significant decrease was observed in all three species at 28 DAT. However, only S. riobrave further declined by 56 DAT.

\subsection{Virulence of EPNs to C. nenuphar Larvae}

No control mortality was observed at 7 and $14 \mathrm{DAT}$, and the untreated control was not included in the analysis. At 7 DAT, mortality was significantly affected by EPN species $(d f=3,162 ; \mathrm{F}=49.35 ; p<0.001)$ and rate $(d f=2,162 ; \mathrm{F}=15.95 ; p<0.001)$; the factors did not interact $(d f=6,156 ; \mathrm{F}=0.70 ; p=0.65)$. Mortality increased with rate except that no mortality was observed with $S$. scarabaei (Table 1 ). Steinernema riobrave caused the highest mortality followed by $S$. carpocapsae, whereas $S$. feltiae caused only minimal mortality. At $14 \mathrm{DAT}$, mortality was significantly affected by EPN species $(d f=3,162 ; \mathrm{F}=72.78 ; p<0.001)$ and rate $(d f=2,162 ; \mathrm{F}=12.98 ; p<0.001)$; the factors did not interact $(d f=6,156 ; \mathrm{F}=1.03$; $p=0.41$ ). At $14 \mathrm{DAT}$, mortality also increased with rate and $S$. riobrave caused the highest mortality followed by S. carpocapsae and S. feltiae, whereas $S$. scarabaei caused the lowest mortality. 


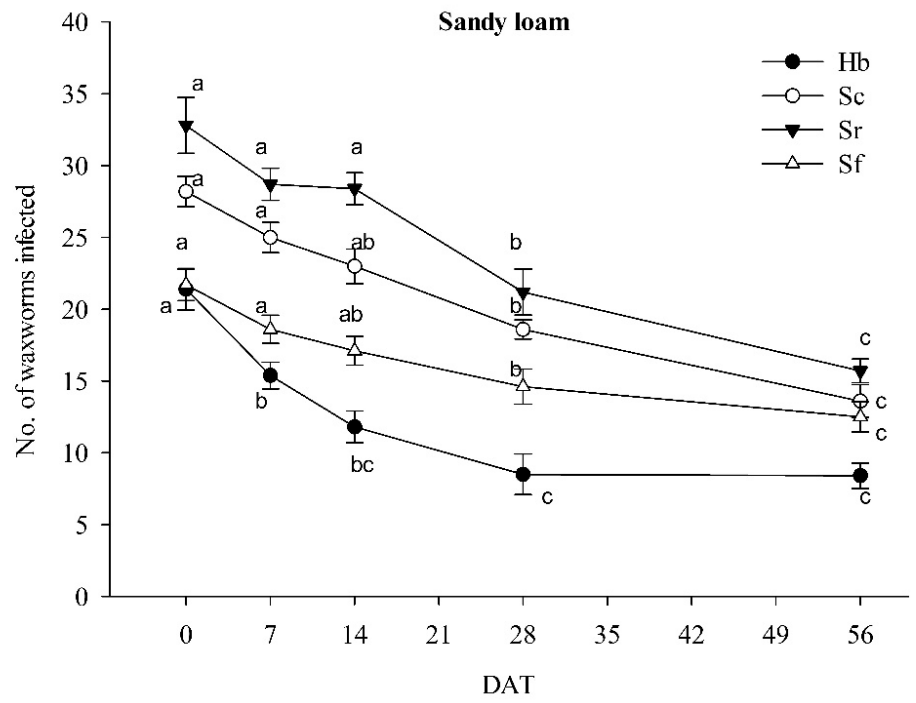

Blueberry soil

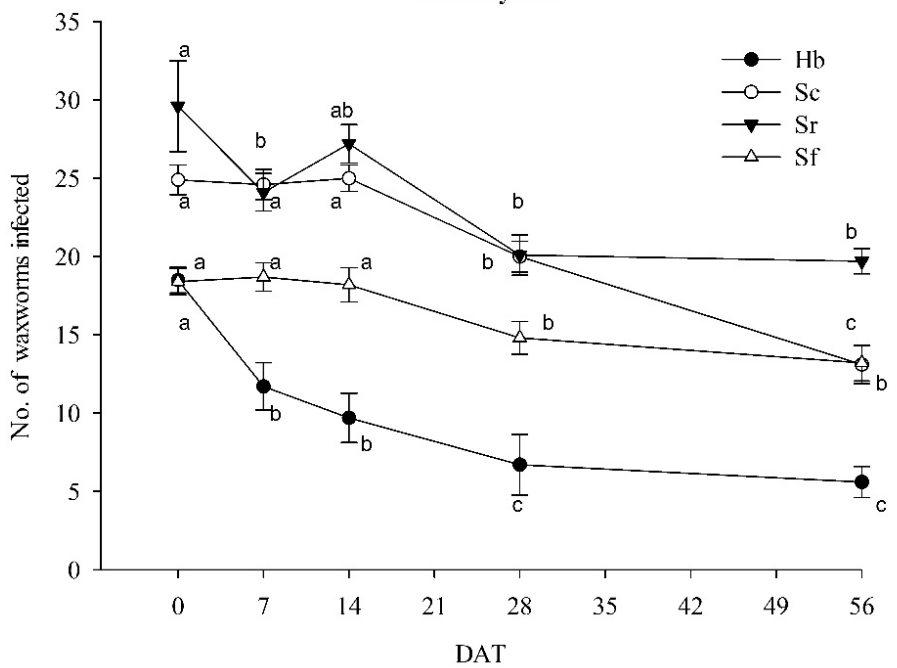

Figure 2. Persistence of the entomopathogenic nematodes Heterorhabditis bacteriophora $(\mathrm{Hb})$, Steinernema carpocapsae (Sc), S. riobrave (Sr), and S. feltiae (Sf) in cups with $100 \mathrm{~g}$ of moist sandy loam (top) and blueberry soil (bottom). Persistence was determined by saturation baiting with waxworms, the larvae of the greater wax moth. Letters next to symbols indicate significant differences in the total number of waxworms infected among baiting dates within species $(p<0.05)$.

Table 1. Percentage mortality ( \pm SEM) of Conotrachelus nenuphar larvae exposed to three rates \# of four entomopathogenic nematode species at 7 and 14 days after treatment (DAT).

\begin{tabular}{ccccc}
\hline IJs/larva & S. feltiae & S. carpocapsae & S. riobrave & S. scarabaei \\
\hline 7 DAT & & & \\
\hline 100 & $1.4 \pm 1.4 \mathrm{Cb}$ & $2.4 \pm 2.4 \mathrm{Bc}$ & $30 \pm 8.1 \mathrm{Ac}$ & $0.0 \pm 0.0 \mathrm{Da}$ \\
200 & $1.4 \pm 1.4 \mathrm{Cb}$ & $8.6 \pm 4.6 \mathrm{Bb}$ & $55.7 \pm 9.4 \mathrm{Ab}$ & $0.0 \pm 0.0 \mathrm{Da}$ \\
400 & $2.9 \pm 2.9 \mathrm{Ca}$ & $35.7 \pm 10.5 \mathrm{Ba}$ & $78.6 \pm 7.4 \mathrm{Aa}$ & $0.0 \pm 0.0 \mathrm{Da}$ \\
\hline $14 \mathrm{DAT}$ & & & \\
\hline 100 & $34.3 \pm 8.0 \mathrm{Bc}$ & $41.4 \pm 5.7 \mathrm{Bc}$ & $94.3 \pm 2.3 \mathrm{Ab}$ & $7.1 \pm 2.7 \mathrm{Cc}$ \\
200 & $41.4 \pm 6.4 \mathrm{Bb}$ & $55.7 \pm 8.1 \mathrm{Bb}$ & $95.7 \pm 2.5 \mathrm{Aa}$ & $27.1 \pm 6.2 \mathrm{Cb}$ \\
400 & $62.9 \pm 7.2 \mathrm{Ba}$ & $61.4 \pm 8.8 \mathrm{Ba}$ & $98.6 \pm 1.4 \mathrm{Aa}$ & $37.1 \pm 4.6 \mathrm{Ca}$ \\
\hline
\end{tabular}

Uppercase letters indicate significant differences between species within rate and DAT $(p<0.05)$. Lowercase letters indicate significant differences between rates within species and DAT $(p<0.05)$. \# Five larvae per cup with $100 \mathrm{~g}$ moist blueberry soil exposed to 500, 1000, or 2000 infective juvenile nematodes per cup. 


\subsection{Virulence of EPNs to C. nenuphar Pupae}

In the first experiment comparing different EPN species, no control mortality was observed at 7 and 14 DAT, and the untreated control was not included in the analysis. At 7 DAT, ANOVA indicated significant differences among treatments $(d f=3,140 ; \mathrm{F}=3.62$; $p<0.05)$. Only $S$. feltiae caused mortality, but also only at $4 \%$. At 14 DAT, mortality was significantly affected by species $(d f=3,140 ; \mathrm{F}=9.64 ; p<0.001)$ (Figure 3 ). Mortality was higher in the S. carpocapsae ( $50 \%$ ) treatment than all others, H. bacteriophora $(0 \%)$, S. scarabaei $(17 \%)$, and S. feltiae (13\%) (Figure 3).

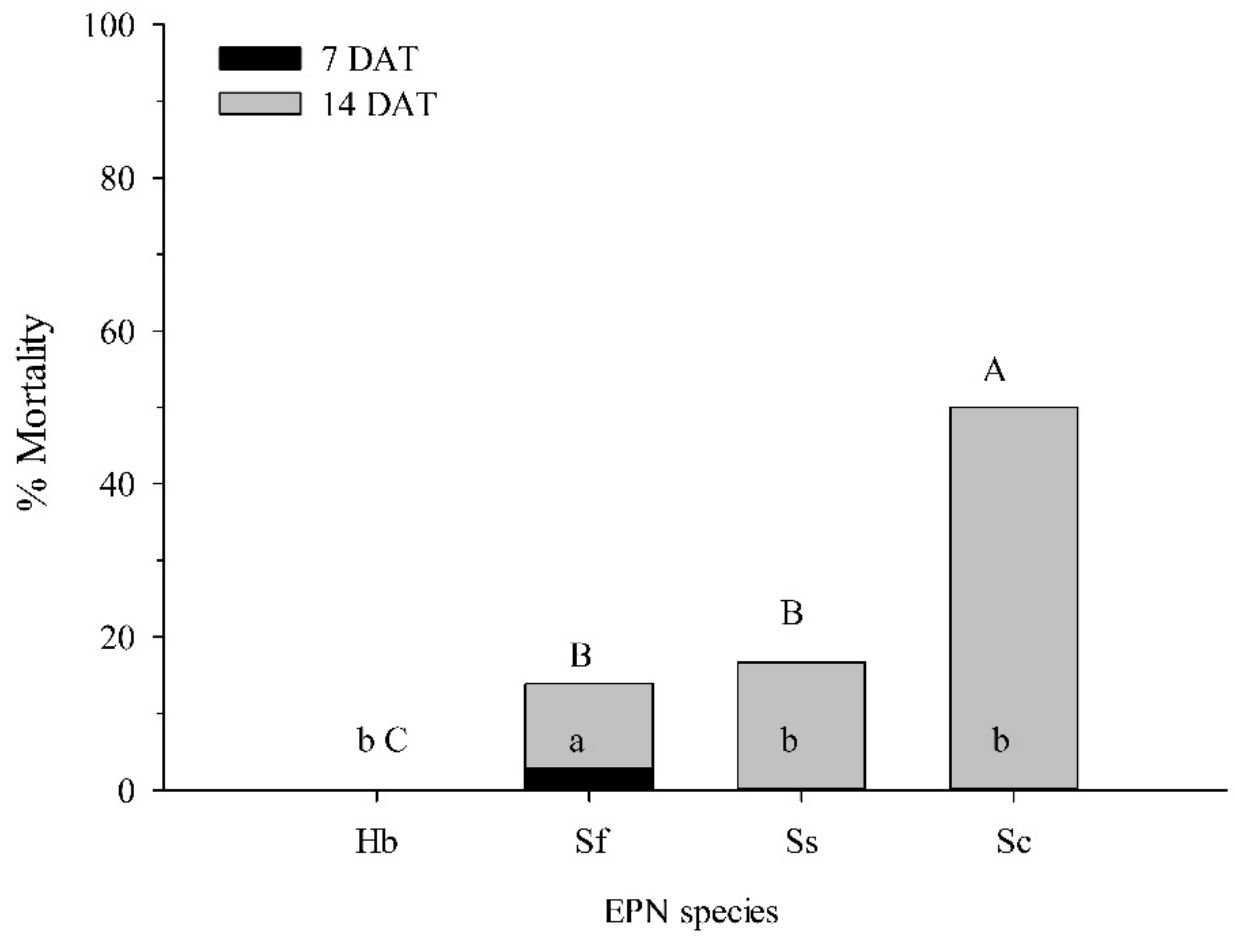

Figure 3. Percentage mortality $( \pm S E M)$ of Conotrachelus nenuphar pupae at 7 and 14 days after treatment (DAT) with 400 infective juveniles of the entomopathogenic nematodes Steinernema carpocapsae (Sc), S. feltiae (Sf), S. scarabaei (Ss), and Heterorhabditis bacteriophora (Hb) in 30-mL cups with $20 \mathrm{~g}$ moist blueberry soil and one pupa. Bars with the same lower and uppercase letter do not differ significantly at 7 and 14 DAT, respectively $(p<0.05)$.

In the second experiment comparing different $S$. riobrave rates, no control mortality was observed at 7 and 14 DAT, and the untreated control was not included in the analysis. At 7 DAT, mortality was already high at all rates $(84-98 \%)$ but was significantly higher at the medium and high rate than at the low rate $(d f=2,237 ; \mathrm{F}=6.20 ; p<0.001)$. At $14 \mathrm{DAT}$, very few additional pupae had been killed but total mortality was significantly higher at the medium and high rates than at the low rate $(d f=2,237 ; \mathrm{F}=12.07 ; p<0.001)$ (Figure 4).

\subsection{Field Experiments: 2020 and 2021}

During the 2020 experiment comparing different EPN species (23 June-10 August 2020), the average (in parentheses absolute) daily high and low temperatures were 31.3 (35.6) ${ }^{\circ} \mathrm{C}$ and $19.3(15.0){ }^{\circ} \mathrm{C}$, respectively. Rainfall totaled $240 \mathrm{~mm}$ and was supplemented with $53 \mathrm{~mm}$ overhead irrigation. Steinernema riobrave provided significantly higher levels of $C$. nenuphar suppression than S. carpocapsae, S. feltiae, and S. scarabaei $(d f=4,29 ; \mathrm{F}=3.80$; $p<0.05)$. There was no difference in $C$. nenuphar adult emergence between $S$. carpocapsae, S. feltiae, and S. scarabaei treatments and the untreated control (Figure 5). 


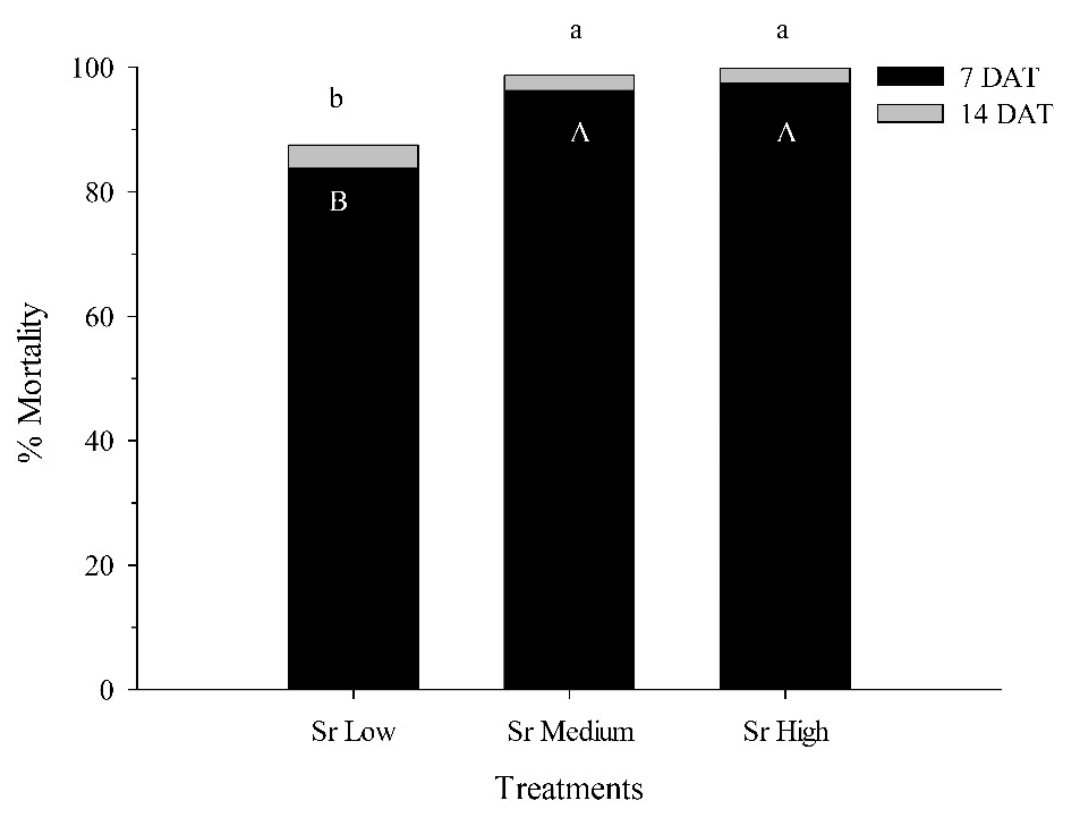

Figure 4. Percentage mortality $( \pm$ SEM) of Conotrachelus nenuphar pupae at 7 and 14 days after treatment (DAT) with three rates $(100,200,400$ infective juveniles) of the entomopathogenic nematodes Steinernema riobrave $(\mathrm{Sr})$ in $30-\mathrm{mL}$ cups with $20 \mathrm{~g}$ moist blueberry soil and one pupa. Bars with same uppercase and lowercase letters do not differ significantly at 7 and 14 DAT, respectively $(p<0.05)$.
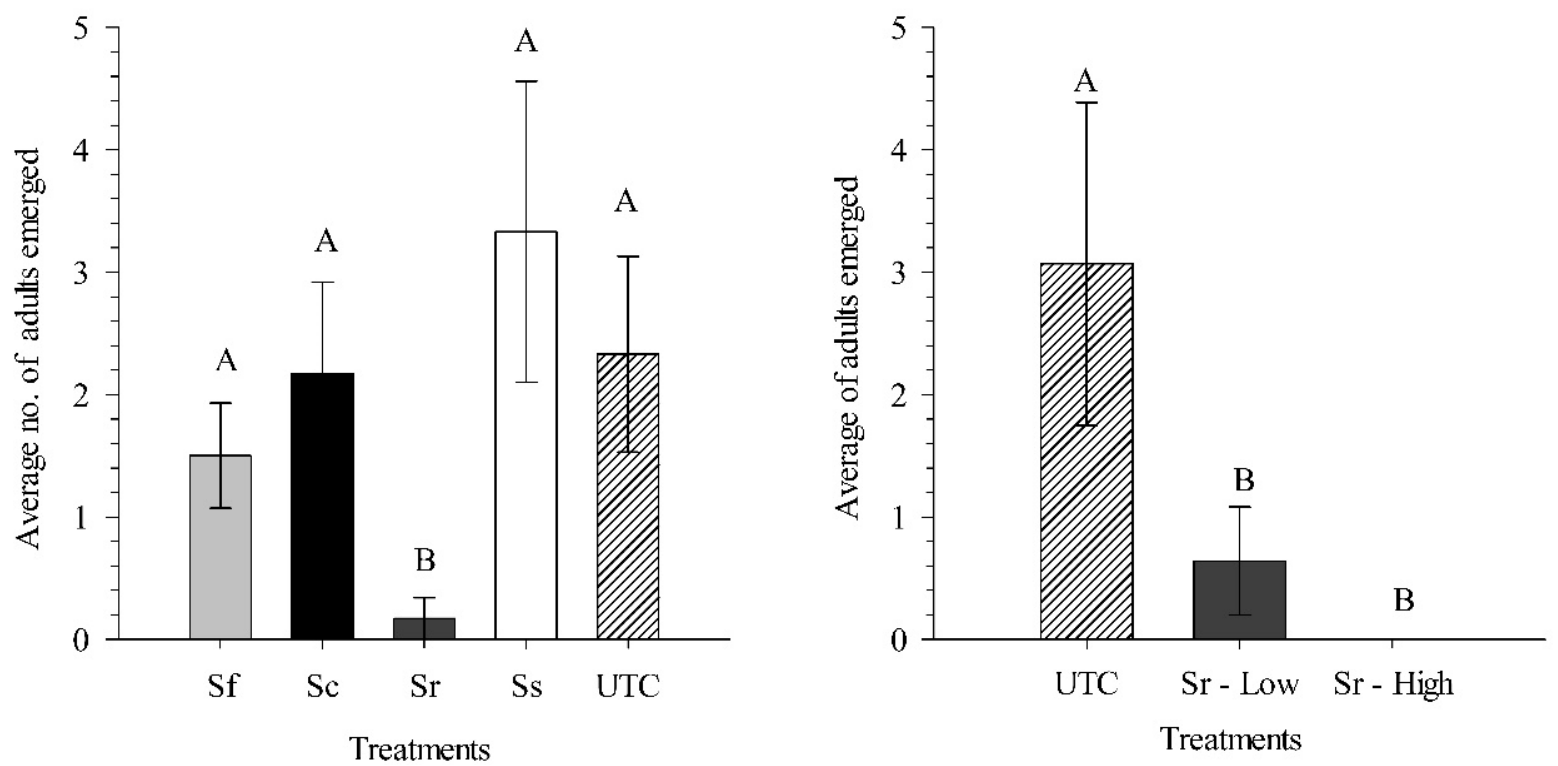

Figure 5. Average number $( \pm \mathrm{SEM})$ of adult Conotrachelus nenuphar emerged from field plots following applications of the entomopathogenic nematodes Steinernema feltiae (Sf), S. carpocapsae (Sc), S. riobrave (Sr), and S. scarabaei (Ss) (all at 50 infective juveniles per $\mathrm{cm}^{2}$ ) in 2020 and following applications of a high and low rate ( 25 and 50 infective juveniles per $\mathrm{cm}^{2}$ ) of $S$. riobrave in 2021 . UTC $=$ untreated control. Bars with the same letters are not statistically different $(p<0.05)$.

During the 2021 experiment comparing S. riobrave rates, the average (in parentheses the absolutes) daily high and low temperatures for the experimental period in field 1 (8 June-15 July 2021) were 29.1 (35.0) ${ }^{\circ} \mathrm{C}$ and 17.5 (8.3) ${ }^{\circ} \mathrm{C}$, respectively. Rainfall totaled $202 \mathrm{~mm}$ and was supplemented with $39 \mathrm{~mm}$ overhead irrigation. In field 2 (16 June15 July 2021), average daily high and low temperatures were $29.7(35.0){ }^{\circ} \mathrm{C}$ and $17.6(8.3){ }^{\circ} \mathrm{C}$, 
respectively. Rainfall totaled $149 \mathrm{~mm}$ and was supplement with $33 \mathrm{~mm}$ of overhead irrigation. Significantly more C. nenuphar adults emerged in the untreated control than at both $S$. riobrave rates $(d f=2,41 ; \mathrm{F}=17.51 ; p<0.001)$. The low and high rates provided $80 \%$ and $100 \%$ control, respectively (Figure 5).

\subsection{Nematode Field Persistence: 2020 and 2021}

In 2020, no waxworms were infected in soil samples from the untreated control plots, which were hence not included in the analysis. EPN species $(d f=6,71 ; \mathrm{F}=17.42 ; p<0.01)$ and sampling day $(d f=2,71 ; \mathrm{F}=140.31 ; p<0.001)$ significantly affected the number of infected waxworms in the soil samples, but the two factors interacted significantly $(d f=6,71 ; F=3.80 ; p<0.01)$. Infection declined significantly over time in all EPN species (Figure 6). However, S. feltiae showed the greatest decline between 0 and 7 DAT with no more significant decline thereafter, whereas the other species declined less dramatically between 0 and 7 DAT but continued to decline until 21 DAT. Infections were the highest for $S$. riobrave, higher than for $S$. feltiae and $S$. scarabaei at 0 to 21 DAT, but higher than $S$. carpocapsae only at 21 DAT. Steinernema feltiae had the lowest number of infections at 7 DAT but did not differ from $S$. scarabaei and S. carpocapsae at 21 DAT.
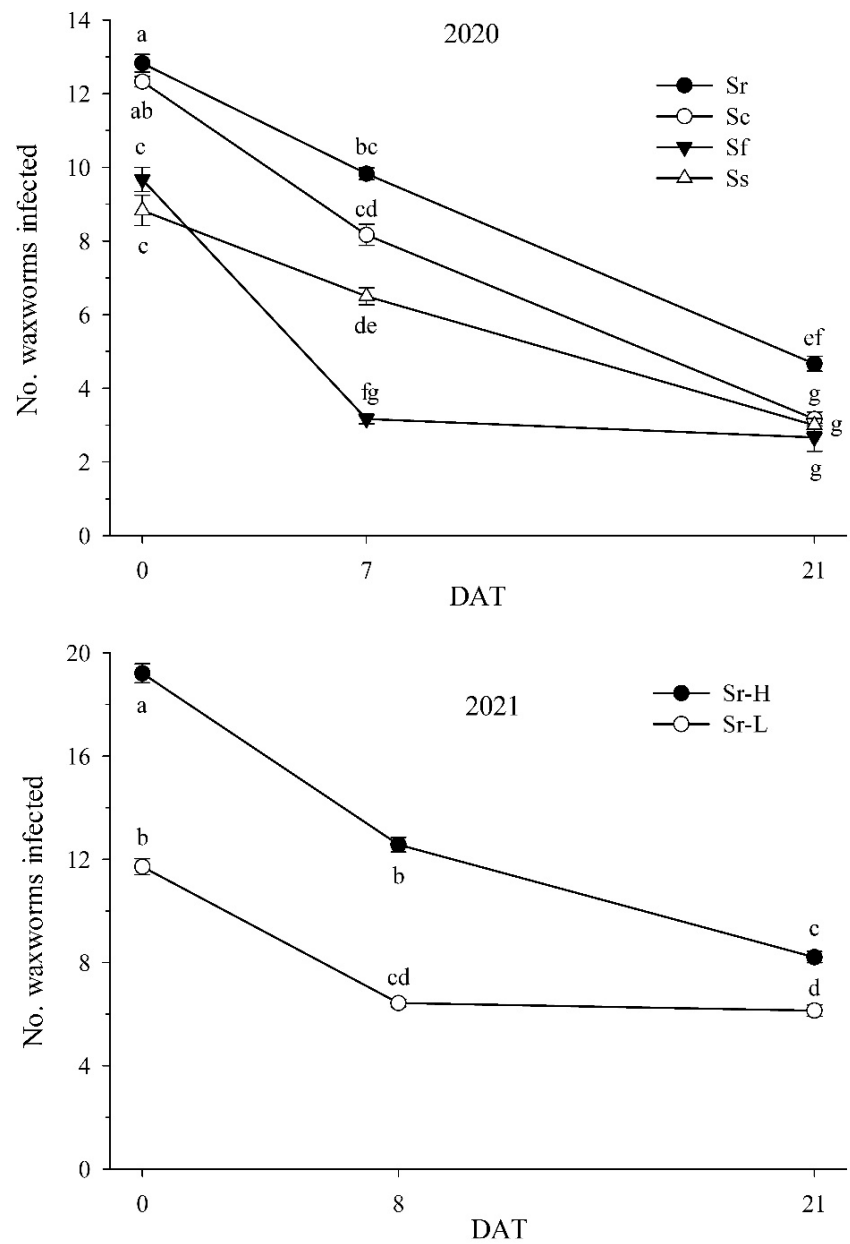

Figure 6. Persistence of the entomopathogenic nematodes Steinernema carpocapsae (Sc), S. riobrave (Sr), S. feltiae (Sf), and S. scarabaei (applied at 50 infective juveniles per $\mathrm{cm}^{2}$ ) in the 2020 field experiment (top) and of $S$. riobrave applied at a low $\left(-\mathrm{L} ; 25\right.$ per $\left.\mathrm{cm}^{2}\right)$ and high $\left(-\mathrm{H} ; 50\right.$ per $\left.\mathrm{cm}^{2}\right)$ rate in the 2021 field experiment (bottom). Persistence was determined by saturation baiting with waxworms of $100 \mathrm{~g}$ soil samples taken from the field plots 0 to 21 days after treatment (DAT). Letters next to symbols indicate significant differences in the total number of waxworms $(p<0.05)$. 
In $2021,2.3 \pm 0.2,1.4 \pm 0.1$, and $2.3 \pm 0.2$ waxworms were infected in samples from the untreated control plots at 0,8 , and 21 DAT, respectively. All these infections were caused by the native Steinernema glaseri, and the untreated control was therefore not included in the analysis. In the treated plots, all infections were caused by $S$. riobrave, and S. riobrave rate $(d f=1,83 ; \mathrm{F}=34.51 ; p<0.001)$, sampling day $(d f=2,83 ; \mathrm{F}=53.85 ; p<0.001)$, and experimental field $(d f=1,83 ; \mathrm{F}=6.91 ; p<0.05)$ significantly affected the number of infected waxworms. Rate did not interact with field $(d f=1,83 ; \mathrm{F}=2.31 ; p=0.11)$ but with sampling day $(d f=2,83 ; \mathrm{F}=3.82 ; p<0.05)$. More $S$. riobrave infections were found on each sampling day at the high rate than at the low rate (Figure 6). However, infections declined progressively at the high rate but only declined from 0 to 8 DAT at the low rate and not thereafter.

\section{Discussion}

Our study clearly demonstrates the superiority and great potential of the EPN $S$. riobrave for the management of $C$. nenuphar in highbush blueberries. Among five EPN species tested it was the most persistent in blueberry soil, was the most virulent against fourth-instar C. nenuphar larvae entering the soil and pupae in laboratory studies and provided the highest level of control in field studies, with excellent control even at relatively low rates.

Under laboratory conditions, persistence of $S$. riobrave was high in sandy loam and acidic sand soils and its recovery did not start to decline until 28 DAT in both soils. Steinernema carpocapsae and S. feltiae demonstrated an intermediary persistence and their recovery started to decline slightly after 14 DAT in both soils. Persistence of H. bacteriophora was much lower in both soil types. Generally, Steinernema spp. appear to persist longer than Heterorhabditis spp. under laboratory and field conditions [28]. According to Koppenhöfer and Fuzy [20], the efficacy of $H$. bacteriophora appears to be generally lower in acidic soil than in common agricultural and turfgrass soils with a slightly acidic to neutral $\mathrm{pH}$. In our study, we observed that the persistence and efficacy of this nematode was lower not only in acidic blueberry soil but also in sandy loam soil with a $\mathrm{pH}$ of 6-6.5. Our 2020 field trial results are consistent with our laboratory results. Steinernema riobrave also demonstrated the highest persistence (=infections) than the others Steinernema spp. In 2021, at the high rate, S. riobrave infections declined on each sampling day, and at the low rate the infections declined from 0 to 8 DAT but not thereafter. Even with the decline for both rates, $S$. riobrave demonstrated excellent persistence. Although there are many factors that can affect EPN performance in different soil types-such as weather conditions, soil particle size composition, $\mathrm{pH}$, organic matter, soil nutrient concentration, length of exposure, water potential, etc. [20,29]-in our study, our focus was to determine the best EPN species to persist and control C. nenuphar in highbush blueberry.

Our laboratory and field results are consistent about $S$. riobrave performance, and they are similar to previous findings that also indicated $S$. riobrave to be highly effective in suppressing $C$. nenuphar in soil applications. In the laboratory, we observed superior virulence of $S$. riobrave against $C$. nenuphar larvae and pupae, and in the field, $S$. riobrave provided significantly higher levels of C. nenuphar suppression (90\%) than S. carpocapsae, S. feltiae, and S. scarabaei. Studies conducted with $S$. riobrave in apple and cherry orchards, in peach orchards and in wild plum thickets located in Michigan, Georgia, and Florida, reported $80-89 \%, 78-100 \%$, and $>94 \%$ C. nenuphar control, respectively $[11,12,17]$. Additionally, Shapiro-Ilan et al. [14] observed $85 \%$ and $97 \%$ C. nenuphar control with S. riobrave in apple orchards in Massachusetts and 100\% control in West Virginia in two years of experiments. In our 2021 study, we confirmed the efficacy of S. riobrave, at low and high rates (25 and $50 \mathrm{IJs} / \mathrm{cm}^{2}$ ), against $C$. nenuphar in blueberry fields and no difference was detected in $C$. nenuphar suppression between the rates. Thus, our research extends that of previous findings in a variety of cropping systems and geographic locations and, also indicates that $S$. riobrave is highly effective in suppressing larvae and pupae of $C$. nenuphar 
in highbush blueberries with acidic blueberry sand in New Jersey. To date, S. riobrave is the most effective EPN tested for C. nenuphar control.

Regarding the other EPN species tested, S. carpocapsae and S. feltiae caused up to around $62 \%$ mortality of $C$. nenuphar larvae in the laboratory, albeit only at high rates, whereas S. scarabaei caused only limited mortality. Against pupae, S. carpocapsae was the only other species that caused significant mortality albeit much lower and slower than S. riobrave. Our laboratory results corroborate previous laboratory research that indicated that $C$. nenuphar is susceptible to various EPN species, such as S. carpocapsae and S. feltiae $[8,10,11,30]$. On the other hand, our field observations in blueberry fields differed from previous studies in other commodities because $S$. carpocapsae and S. feltiae did not suppress $C$. nenuphar at all, whereas $S$. riobrave was highly effective. Other studies have reported variable and reduced impacts of S. carpocapsae and S. feltiae on C. nenuphar in different crops. For example, Pereault et al. [17] observed that $S$. carpocapsae was less effective than S. riobrave in apple and cherry orchards in Michigan. Alston et al. [30] observed that S. feltiae applications produced low (22-39\%) levels of C. nenuphar control in wild plum sites in Utah, and Shapiro-Ilan et al. [11] observed no suppression when using S. feltiae in Georgia and Florida peach orchards. Additionally, Shapiro-Ilan et al. [14] observed an intermediate level of control by S. feltiae, but the level of suppression was not consistent and was lower than the level of control provided by S. riobrave in apple orchards located in West Virginia and Massachusetts. The greater lag of S. carpocapsae and S. feltiae in our studies may be related to the better ability of $S$. riobrave to persist and to infect hosts in the highly acidic blueberry sand that adds to its higher virulence.

Steinernema scarabaei was included in our study because it can provide excellent control (86-95\%) of another important pest of highbush blueberries, the larvae of $A$. orientalis [24]. In addition, laboratory data suggest that the low $\mathrm{pH}$ of typical blueberry soil has no negative effect on S. scarabaei persistence [20] and this EPN may therefore have good potential for long-term white grub suppression in blueberries [24]. Thus, a S. scarabaei application in June for $C$. nenuphar control may also control A. orientalis larvae appearing in the soil in July. However, in our study, this EPN species demonstrated limited potential as a C. nenuphar control agent in both laboratory and field experiments.

\section{Conclusions}

Our laboratory results match with our field findings and show that $S$. riobrave is, by far, the most effective EPN species to suppress C. nenuphar larvae and pupae in acidic blueberry soils. According to Shapiro-Ilan et al. [31], the use of S. riobrave as a component of an integrated program that targets multiple stages of $C$. nenuphar may be feasible. We here showed that $S$. riobrave can infect both larvae and pupae of $C$. nenuphar at different rates and is also very persistent in acidic blueberry soil, indicating that applications of this nematode species could control multiple stages (larvae and pupae) of $C$. nenuphar in the typically highly acidic blueberry sands. Future research should examine optimal timing of EPN application and combination with other management tools to develop and implement a multi-stage integrated pest management program for C. nenuphar in highbush blueberries.

Supplementary Materials: The following supporting information can be downloaded at: https: / / www.mdpi.com/article/10.3390/biology11010045/s1.

Author Contributions: A.L.S., conceptualization, methodology, investigation, formal analysis, writing - original draft preparation, visualization. C.R.-S., conceptualization, methodology, resources, writing-review and editing, supervision. R.H., conceptualization, methodology, investigation. V.K.-R., conceptualization, methodology, investigation. A.M.K., conceptualization, methodology, formal analysis, resources, writing-review and editing, supervision. All authors have read and agreed to the published version of the manuscript.

Funding: This work was supported by the New Jersey Blueberry and Cranberry Research Council.

Institutional Review Board Statement: Not applicable. 
Informed Consent Statement: Not applicable.

Data Availability Statement: The data presented are available in the Supplementary Materials.

Acknowledgments: The authors thank Robert McDougall (Nielsen Fruit Entomology Lab), Jennifer Frake, Amanda Quadrel, Timothy Schwanitz (Blueberry/Cranberry Entomology Lab) and Victoria Appel, Rebbeka Figueiredo, Shane Foye (Turfgrass Entomology Lab) for assisting with laboratory and field work.

Conflicts of Interest: The authors declare no conflict of interest.

\section{References}

1. Racette, G.; Chouinard, G.; Vincent, C.; Hill, S.B. Ecology and management of plum curculio, Conotrachelus nenuphar [Coleoptera: Curculionidae], in apple orchards. Phytoprotection 1992, 73, 85-100. [CrossRef]

2. Horton, D.; Johnson, D. (Eds.) Southeastern Peach Grower's Handbook; University of Georgia, Cooperative Extension Service: Athens, GA, USA, 2005.

3. Leskey, T.C.; Chouinard, G.; Vincent, C. Monitoring and management of apple maggot fly and plum curculio: Honouring the legacy of Ronald J. Prokopy. In Biorational Tree Fruit Management; Aluja, M., Leskey, T.C., Vincent, C., Eds.; CABI Press: Oxfordshire, UK, 2009; p. 295.

4. Antonelli, A.; Elsner, E.; Shanks, C. Arthropod Management. In Highbush Blueberry Production Guide; Northeast Regional Agricultural Engineering Service-55; Cooperative Extension: Ithaca, NY, USA, 1992; pp. 55-75.

5. Levine, E.; Hall, F.R. Effect of feeding and oviposition by the plum curculio on apple and plum fruit abscission. J. Econ. Entomol. 1977, 70, 603-607. [CrossRef]

6. Quaintance, A.L.; Jenne, E.L. The Plum Curculio (No. 103); US Department of Agriculture, Bureau of Entomology: Washington, DC, USA, 1912.

7. Lampasona, T.P.; Rodriguez-Saona, C.; Leskey, T.C.; Nielsen, A.L. A Review of the biology, ecology, and management of plum curculio (Coleoptera: Curculionidae). J. Integr. Pest Manag. 2020, 11, 22. [CrossRef]

8. Olthof, T.H.; Hagley, E.A.C. Laboratory studies of the efficacy of steinernematid nematodes against the plum curculio (Coleoptera: Curculionidae). J. Econ. Entomol. 1993, 86, 1078-1082. [CrossRef]

9. Horton, D.; Brannen, P.; Bellinger, B.; Lockwood, D.; Ritchie, D. Southeastern Peach, Nectarine, and Plum Pest Management and Culture Guide, Bulletin 1171; University of Georgia: Athens, GA, USA, 2013.

10. Shapiro-Ilan, D.I.; Mizell, R.F.; Campbell, J.F. Susceptibility of the plum curculio, Conotrachelus nenuphar, to entomopathogenic nematodes. J. Nematol. 2002, 34, 246-249. [PubMed]

11. Shapiro-Ilan, D.I.; Mizell, R.F.; Cottrell, T.E.; Horton, D.L. Measuring field efficacy of Steinernema feltiae and Steinernema riobrave for suppression of plum curculio, Conotrachelus nenuphar, larvae. Biol. Control 2004, 30, 496-503. [CrossRef]

12. Shapiro-Ilan, D.I.; Mizell III, R.F.; Cottrell, T.E.; Horton, D.L. Control of plum curculio, Conotrachelus nenuphar with entomopathogenic nematodes: Effects of application timing, alternate host plant, and nematode strain. Biol. Control 2008, 44, $207-215$. [CrossRef]

13. Shapiro-Ilan, D.I.; Leskey, T.C.; Wright, S.E. Virulence of entomopathogenic nematodes to plum curculio, Conotrachelus nenuphar: Effects of strain, temperature, and soil type. J. Nematol. 2011, 43, 187-195. [PubMed]

14. Shapiro-Ilan, D.I.; Wright, S.E.; Tuttle, A.F.; Cooley, D.R.; Leskey, T.C. Using entomopathogenic nematodes for biological control of plum curculio, Conotrachelus nenuphar: Effects of irrigation and species in apple orchards. Biol. Control 2013, 67, 123-129. [CrossRef]

15. Kaya, H.K.; Gaugler, R. Entomopathogenic nematodes. Annu. Rev. Entomol. 1993, 38, 181-206. [CrossRef]

16. Shapiro-Ilan, D.I.; Duncan, L.W.; Lacey, L.A.; Han, R. Orchard crops. In Nematodes as Biological Control Agents; Grewal, P., Ehlers, R.-U., Shapiro-Ilan, D.I., Eds.; CABI Publishing: Wallingford, UK, 2005; pp. 215-230.

17. Pereault, R.J.; Whalon, M.E.; Alston, D.G. Field efficacy of entomopathogenic fungi and nematodes targeting caged last-instar plum curculio (Coleoptera: Curculionidae) in Michigan cherry and apple orchards. Environ. Entomol. 2009, 38, 1126-1134. [CrossRef] [PubMed]

18. Piñero, J.C.; Shapiro-Ilan, D.I.; Cooley, D.R.; Tuttle, A.F.; Eaton, A.; Drohan, P.; Leahy, K.; Zhang, A.; Hancock, T.; Wallingford, A.K.; et al. Toward the integration of an attract-and-kill approach with entomopathogenic nematodes to control multiple life stages of plum curculio (Coleoptera: Curculionidae). Insects 2020, 11, 375. [CrossRef]

19. Shapiro-Ilan, D.I.; Bruck, D.J.; Lacey, L.A. Principles of epizootiology and microbial control. Insect Pathol. 2012, 2, $29-72$.

20. Koppenhöfer, A.M.; Fuzy, E.M. Effect of soil type on infectivity and persistence of the entomopathogenic nematodes Steinernema scarabaei, Steinernema glaseri, Heterorhabditis zealandica and Heterorhabditis bacteriophora. J. Invertebr. Pathol. 2006, 92, 11-22. [CrossRef] [PubMed]

21. Hamblin, A.P. Filter-paper method for routine measurement of field water potential. J. Hydrol. 1981, 53, 355-360. [CrossRef]

22. Amis, A.; Snow, J.J. Conotrachelus nenuphar. In Handbook of Insect Rearing; Singh, P., Moore, R.F., Eds.; Elsevier: Amsterdam, The Netherlands, 1985; pp. 227-236. 
23. Koppenhöfer, A.M.; Kaya, H.K.; Campbell, J.F.; Gaugler, R. Estimation of entomopathogenic nematode population density in soil by correlation between bait insect mortality and nematode penetration. Fund. Appl. Nematol. 1998, 21, 95-102.

24. Polavarapu, S.; Koppenhöfer, A.M.; Barry, J.D.; Holdcraft, R.; Fuzy, E.M. Entomopathogenic nematodes and neonicotinoids for remedial control of oriental beetle, Anomala orientalis (Coleoptera: Scarabaeidae), in highbush blueberry. Crop Prot. 2007, 26, 1266-1271. [CrossRef]

25. Koppenhöfer, A.M.; Fuzy, E.M. Long-term effects and persistence of Steinernema scarabaei applied for suppression of Anomala orientalis (Coleoptera: Scarabaeidae). Biol. Control 2009, 48, 63-72. [CrossRef]

26. Kaya, H.K.; Stock, S.P. Techniques in insect nematology. In Manual of Techniques in Insect Pathology; Lacey, L.A., Ed.; Academic Press: San Diego, CA, USA, 1997; pp. 281-324.

27. Koppenhöfer, A.M. Nematodes. In Field Manual of Techniques for the Application and Evaluation of Entomopathogens, 2nd ed.; Lacey, L., Kaya, H., Eds.; Kluwer: Dordrecht, The Netherlands, 2007; pp. 249-264.

28. Baur, M.E.; Kaya, H.K. Persistence of entomopathogenic nematodes. In Factors Affecting the Survival of Entomopathogens; Baur, M.E., Fuxa, J.R., Eds.; Southern Cooperative Series Bulletin: Fayetteville, AR, USA, 2001.

29. Koppenhöfer, A.M.; Fuzy, E.M. Soil moisture effects on infectivity and persistence of the entomopathogenic nematodes Steinernema scarabaei, S. glaseri, Heterorhabditis zealandica, and H. bacteriophora. Appl. Soil Ecol. 2007, 35, 128-139. [CrossRef]

30. Alston, D.G.; Rangel, D.E.N.; Lacey, L.A.; Golez, H.G.; Kim, J.J.; Roberts, D.W. Evaluation of novel fungus and nematode isolates for control of Conotrachelus nenuphar (Coleoptera: Curculionidae) larvae. Biol. Control 2005, 35, 163-171. [CrossRef]

31. Shapiro-Ilan, D.I.; Arthurs, S.P.; Lacey, L.A. Microbial control of arthropod pests of orchards in temperate climates. In Microbial Control of Insect and Mite Pests; Lacey, L.A., Ed.; Elsevier: Amsterdam, The Netherlands, 2017; pp. 253-267. [CrossRef] 